DOI https://doi.org/10.30525/978-9934-588-81-5-1.38

\title{
DENTAL STATUS ANALYSIS IN CHILDREN WITH INSULIN-DEPENDENT DIABETES MELLITUS
}

\author{
Maksymenko A. I. \\ Candidate of Medical Sciences, \\ Associate Professor at the Department of Pediatric Dentistry \\ Ukrainian Medical Stomatological Academy \\ Kuz I. 0. \\ Postgraduate at the Department of Pediatric Dentistry \\ Ukrainian Medical Stomatological Academy \\ Sheshukova O. V. \\ Doctor of Medical Sciences, \\ Professor at the Department of Pediatric Dentistry \\ Ukrainian Medical Stomatological Academy \\ Poltava, Ukraine
}

Diabetes mellitus is one of the most common metabolic diseases, which leads to many complications of various organs and systems of the human body. Type I (insulin-dependent) diabetes is more common in children and adolescents and occurs as a result of the autoimmune destruction of $\beta$-cells in the pancreas. As a result, the amount of insulin secretion decreases and the level of glucose in the blood rises. Metabolic changes such as xerostomia and increased salivary glucose levels can lead to a high prevalence of dental diseases in children with diabetes. [1, p. 52-53].

Diabetes mellitus is characterized by a high prevalence, lifelong course, early disability and high mortality rates. Diabetes mellitus ranks third in terms of morbidity and mortality in developed countries. [2, p. 199-204].

Many studies indicate a higher frequency and severity of gingivitis and periodontitis in children and adolescents with type I diabetes mellitus compared with healthy children. [7, p. 37-44.] According to scientists, the severity and frequency of periodontal disease were statistically more noticeable in patients with type I diabetes and concomitant periodontal pathology compared with non-diabetic persons of this age. [4, p. 265-273].

The presence of type I diabetes mellitus in children is the main risk factor for periodontitis. Due to hypoglycemia, metabolism in the periodontal tissues is disturbed, which in turn leads to the progression of inflammatory and degenerative processes in the oral cavity. [5, p. 119-126]. The patho- 
genetically important common features for endocrinological diseases and periodontal pathologies are, first of all, angiopathy at the level of the vessels of the microvasculature, metabolic disorders, changes in lipid peroxidation, autoaggression, and the occurrence of secondary immunodeficiency. [8, p. 10-15].

These general mechanisms can be explained by the following factors: microvascular disorders, changes in the composition of the gums and oral fluid, changes in collagen metabolism, changes in the body's immune response, increased presence of pathogenic microorganisms, genetic predisposition. [9, p. 122-126]. Generally, there must be biological mechanisms underlying the pathological interactions to confirm the relationship between diabetes and gingivitis and periodontitis. These mechanisms are very similar to classic diabetic complications such as retinopathy, nephropathy, microvascular and macrovascular diseases, and wound healing disorders. [3, p. 130-135].

Thus, a deep and comprehensive study of the above relationship is necessary, and the development of therapeutic measures in patients with inflammatory periodontal diseases is especially relevant. [6, p. 369-381].

Purpose of the study. To determine the structure of dental morbidity in children with insulin-dependent diabetes mellitus.

Materials and methods. Dental examination of 62 children 12-16 years old on the basis of children's outpatient department № 3 in Poltava. There were 34 girls (54.8\%) and 28 boys (45.2\%), and the average age of children was $14 \pm 1.23$ years. Children were divided into 2 clinical groups: 31 children with type I diabetes mellitus (severe form) in the stage of carbohydrate metabolism subcompensation and 31 people without concomitant pathology. The prevalence and intensity of caries (according to CPV indicators) were determined in all subjects, the condition of the periodontal tissues (PMA), the oral mucosa and the red border of the lips was assessed. Oral hygiene was determined by the Green-Vermilion Index (OHI-S). Statistical processing of the research results was carried out using generally accepted methods of variation statistics.

Results and their discussion. Our study shows a significant increase of the manifestations of periodontal tissue diseases and oral mucosa in children with diabetes. Chronic generalized catarrhal gingivitis of varying severity was diagnosed in 23 children (74.2\%) from the first group, and in the second group - in 10 people (32.3\%). Edema, pastiness, anemicity of the oral mucosa, dental prints on the lateral surface of the tongue and cheeks were observed in 18 patients $(58.1 \%)$ with diabetes mellitus. All children with diabetes mellitus complained about intermittent dryness and 
astringency in the mouth; such complaints were not found in practically healthy children. Angular cheilitis was revealed in 2 children (6.5\%) from the first group.

The prevalence of caries was high both among children with diabetes $(93.5 \%)$ and in the group of apparently healthy children $(83.9 \%)$. The intensity of caries in children with diabetes was higher $(2.7 \pm 1.5)$ than in children without concomitant pathology $(1.9 \pm 1.6)$.

We concluded that there were no differences in the level of the hygienic state of the oral cavity, both within the group of patients with diabetes $(\mathrm{OHI}-\mathrm{S}=1.7 \pm 0.4)$ and when compared with practically healthy children $(\mathrm{OHI}-\mathrm{S}=1.9 \pm 0.3)$. [1, p. 52-53].

Conclusions. There are certain changes in the oral cavity in children with insulin-dependent diabetes mellitus, compared with children without such pathology, which consist in a high level of prevalence and intensity of periodontal tissue inflammation and a higher intensity of the carious process.

To detect pathological changes in the oral cavity in time, it is important to make regular dental monitoring in children with endocrine system diseases and to learn them the rules of oral hygiene.

\section{References:}

1. Максименко A.I. Аналіз стоматологічного статусу у дітей з інсулінозалежним цукровим діабетом / А.І. Максименко // Матеріали наук.-практ. конф. з міжнар. участю «Сучасні аспекти теоретичної та практичної стоматологї̈», 4-5 травня 2020 року. - Чернівці, 2020. - C. 52-53.

2. Кузь I.О. Догляд за ротовою порожниною та вибір лікарських препаратів при захворюваннях пародонту у дітей з цукровим діабетом I типу / Кузь I.О., Шешукова О.В. // Актуальні проблеми сучасної медицини: Вісник УМСА. - 2020. - Том 20, № 1 (69). - С. 199-204.

3. Кузь I.О. Взаємозв'язок цукрового діабету I типу та захворювань пародонта у дітей / Кузь I.О., Шешукова О.В. // Актуальні проблеми сучасної медицини: Вісник УМСА. - 2019. - Том 19, № 4 (68). C. $130-135$.

4. Daković D. Gingivitis and periodontitis in children and adolescents suffering from type 1 diabetes mellitus. / Daković D, Mileusnić I, Hajduković Z, Čakić S, Hadži-Mihajlović M. // Vojnosanit Pregl. - 2015. № 72(3) - P. 265-273.

5. Díaz Rosas CY. Dental, periodontal and salivary conditions in diabetic children associated with metabolic control variables and nutritional plan adherence. / Díaz Rosas CY, Vargas E Cárdenas, Castañeda-Delgado 
JE, Aguilera-Galaviz LA, Aceves Medina MC. // European Journal of Paediatric Dentistry. - 2018. - № 19(2) - P.119-126.

6. Ismail AF. Oral health of children with type 1 diabetes mellitus: A systematic review. / Ismail AF, Mcgrathb CP, Yiu KYC. // Diabetes Research and Clinical Practice. - 2015. - № 108(3) - P. 369-381.

7. Kuźmiuk A. Importance of dental care to maintain oral health of children and youth with type 1 diabetes. / Kuźmiuk A, Marczuk-Kolada G, Łuczaj-Cepowicz E, Obidzńska M, Chorzewska E, Wasilczuk U, Kierklo A, Szajda SD. // Medycyna Pracy. - 2018. - № 69(1) - P. 37-44.

8. Punthakee Z. Definition, Classification and Diagnosis of Diabetes, Prediabetes and Metabolic Syndrome. / Punthakee Z, Goldenberg R, Katz P. // Canadian Journal of Diabetes. - 2018 - № 42(1) - P. 10-15.

9. Rafatjou R. Dental Health Status and Hygiene in Children and Adolescents with Type 1 Diabetes Mellitus. / Rafatjou R, Razavi Z, Tayebi S, Khalili M, Farhadian M. // Journal of Research in Health Sciences. - 2016- № 16(3) - P. 122-126.

DOI https://doi.org/10.30525/978-9934-588-81-5-1.39

\title{
АЛГОРИТМ ТЕЛЕФОННИХ КОНСУЛЬТАЦЙ СІМЕЙНОГО ЛІКАРЯ В УМОВАХ ПАНДЕМІЇ COVID 19
}

\author{
Матейко Г. Б. \\ доктор медичних наук, професор, \\ завідувач кафедри дитячих інфекиійних хвороб \\ Івано-Франківський національний медичний університет \\ Антонюк Л. В. \\ асистент кафедри дитячих інфекиійних хвороб \\ Івано-Франківський національний медичний університет \\ Глушко У. А. \\ асистент кафедри дитячих інфекиійних хвороб \\ Івано-Франківський національний медичний університет \\ м. Івано-Франківськ, Украӥна
}

Професіоналізм лікаря визначається не тільки тим, наскільки добре він знає етіологію і патогенез хвороби, методи ії діагностики та лікування, але і його вмінням консультувати, тобто спілкуватися, вчити, радити. Уміння лікаря спілкуватися визначає його взаємини з хворим - 